\title{
Evidence that Epithelial Glycoprotein 330/Megalin Mediates Uptake of Polybasic Drugs
}

\author{
Søren Kragh Moestrup, Shiying Cui, ${ }^{*}$ Henrik Vorum, Claus Bregengård, ${ }^{\ddagger}$ Søren Erik Bjørn, ${ }^{\ddagger}$ Kjeld Norris, \\ Jørgen Gliemann, and Erik Ilsø Christensen* \\ Department of Medical Biochemistry and *Department of Cell Biology, Institute of Anatomy, University of Aarhus, 8000 Aarhus C, \\ Denmark; and ${ }^{\ddagger}$ Novo Nordisk, Bioscience, 2880 Bagsverd, Denmark
}

\begin{abstract}
Glycoprotein 330 (gp330) is an endocytic receptor expressed in the renal proximal tubules and some other absorptive epithelia, e.g., in the inner ear. The present study shows that the antifibrinolytic polypeptide, aprotinin, and the nephroand ototoxic antibiotics, aminoglycosides, and polymyxin $B$ compete for binding of ${ }^{125} \mathrm{I}$-urokinase-plasminogen activator inhibitor type-1 complexes to purified rabbit gp330. Half maximal inhibition was measured at $4 \mu \mathrm{M}$ for aprotinin, $50 \mu \mathrm{M}$ for gentamicin, and $0.5 \mu \mathrm{M}$ for polymyxin B. Drug binding to $\mathrm{gp} 330$ was validated by equilibrium dialysis of $\left[{ }^{3} \mathrm{H}\right]$ gentamicin-gp330 incubations and binding/uptake studies in rat proximal tubules and gp330-expressing L2 carcinoma cells. Analyses of mutant aprotinins expressed in Saccharomyces cerevisiae revealed that basic residues are essential for the binding to gp330 and renal uptake. The polybasic drugs also antagonized ligand binding to the human $\alpha_{2}$-macroglobulin receptor. However, the rapid glomerular filtration of the drugs suggests kidney gp330 to be the quantitatively most important target.

In conclusion, a novel role of gp330 as a drug receptor is demonstrated. The new insight into the mechanism of epithelial uptake of polybasic drugs might provide a basis for future design of drugs with reduced toxicity. (J. Clin. Invest. 1995. 96:1404-1413.) Key words: glycoprotein 330 • low density lipoprotein receptor-related protein • kidney • aminoglycosides • endocytosis
\end{abstract}

\section{Introduction}

Glycoprotein 330 (gp330) ${ }^{1}$ alias Heymann Nephritis autoantigen (1) and megalin (2) is an $\sim 600 \mathrm{kD}(2-6)$ protein expressed in the renal tubule epithelium and a few other specialized epithelial cell types, e.g., retinal and inner ear epithelium

Address correspondence to S. K. Moestrup, Department of Medical Biochemistry, University of Aarhus, Blgn. 170, DK-8000 Aarhus C, Denmark. Phone: 45-89-422850; FAX: 45-86-131160.

Received for publication 16 February 1995 and accepted in revised form 28 April 1995.

1. Abbreviation used in this paper: $\alpha_{2} \mathrm{MR} / \mathrm{LRP}, \alpha_{2}$-macroglobulin receptor/LDL receptor-related protein; gp330, glycoprotein 330; PAI-1, plasminogen activator inhibitor type-1; RAP, receptor-associated protein.

J. Clin. Invest.

(C) The American Society for Clinical Investigation, Inc.

0021-9738/95/09/1404/10 \$2.00

Volume 96, September 1995, 1404-1413
(7-9). cDNA cloning $(2,10)$ has demonstrated that gp330 is a member of the LDL receptor family. This also includes the homologous $600-\mathrm{kD}$ multiligand $\alpha_{2}$-macroglobulin receptor $\left(\alpha_{2} \mathrm{MR}\right)$ also called LDL receptor-related protein (LRP) (for review see references 11,12$)$. Both receptors are anionic proteins and gp330 has an estimated pI at 4.6 (13). In contrast to gp330, $\alpha_{2}$ MR/LRP is expressed in several cell types facing the circulation (e.g., mononuclear phagocytes and hepatocytes), while no expression is observed in gp330-expressing epithelia in the kidney and inner ear $(7-9,14)$.

$\alpha_{2}$ MR/LRP and gp330 bind $\mathrm{Ca}^{2+}$ and several common ligands including plasminogen activators in complex with their type-1 inhibitor (PAI-1), plasminogen, lipoprotein lipase, and the 39-40-kD receptor-associated protein (RAP) $(4,5,6,15-$ 17). Studies on $\alpha_{2} M R / L R P$ suggest that charge interactions between basic regions of the ligands and negatively charged complement-type repeats (synonymous to LDL receptor-like repeats) are essential for ligand/receptor interaction $(18,19)$. Studies of the uptake of ${ }^{125}$ I-labeled RAP and urokinase PAI-1 complexes in perfused rat and rabbit proximal tubules $(4,20)$ have established the function of gp330 as an endocytosis-mediating receptor of protein ligands. In addition to this function, the strong affinity for $\mathrm{Ca}^{2+}(4)$ and a suggested function as a $\mathrm{Ca}^{2+}$ sensor in the parathyroid glands (21) might indicate a role in the $\mathrm{Ca}^{2+}$ homeostasis.

The cationic nature of several established ligands to gp330 led us to investigate gp330 binding of three main types of polybasic drugs known to accumulate in renal cortex.

Aminoglycosides are antibiotics commonly used to treat gram-negative infections. Unfortunately, they are frequently associated with severe nephro- and ototoxicity as a direct consequence of lysosomal accumulation in the kidney proximal tubules and inner ear epithelium (22-25). Aminoglycosides are taken up in proximal tubules ( $\mathrm{S} 1$ and $\mathrm{S} 2$ segments) by a receptor-mediated mechanism as judged by electron microscopic localization of aminoglycosides in coated pits and endocytic compartments $(23,24,26-28)$. A common uptake mechanism in the ear and kidney has been suggested (29). Acidic phospholipids are assumed to be the initial epithelial binding site (25), but no endocytic receptors mediating uptake of aminoglycosides have so far been identified.

Aprotinin alias bovine pancreatic trypsin inhibitor is a 6$\mathrm{kD}$ protein with a clinical potential in acute pancreatitis and antifibrinolytic therapy. Intravenously administrated aprotinin accumulates in the lysosomes of kidney proximal tubules $(30$, 31 ) and is only very slowly degraded (30) in accordance with $x$ ray crystallographic analysis of aprotinin demonstrating a highly compact and stable tertiary structure (32).

Polymyxin $\mathrm{B}$ is a $1-\mathrm{kD}$ polycationic cyclic peptide antibiotic with detergent effects on gram-negative bacteria. It also accumulates in the proximal tubules, and due to side effects such 
as nephrotoxicity, it is only recommended for external use (33, 34). Besides its antimicrobial activity, polymyxin $B$ is a potent inhibitor of endotoxin via binding to the lipid A part of endotoxin (35).

In the present study we have investigated binding of aminoglycosides, e.g., gentamicin, aprotinin, and polymyxin B to gp330 and the uptake mediated via this receptor, as well as the binding to $\alpha_{2}$ MR/LRP. In addition, a panel of recombinant aprotinin mutants with a diversity of net charges was analyzed. We find that the drugs bind to gp330 as well as to $\alpha_{2}$ MR/LRP and provide evidence that the renal uptake occurs via gp330. By site-directed mutagenesis we show that the polybasic nature of aprotinin determines the affinity for the receptor.

\section{Methods}

Receptors, ligands and polybasic drugs. Rabbit gp330 was purified from solubilized rabbit kidney cortex membranes by RAP-affinity chromatography (20). Human two-chain $\alpha_{2} M R / L R P$ was purified from solubilized membrane preparations from newborn placenta by $\alpha_{2}$-macroglobulinmethylamine-affinity chromatography (15). RAP was produced as a recombinant protein in Escherichia coli transfected with cDNA encoding human RAP (36). Human urokinase-PAI-1 complexes were kindly provided by Drs. A. Nykjær and P. Andreasen, University of Aarhus, Denmark. Aprotinin and mutants were produced as recombinant proteins in Saccharomyces cerevisiae as described (37). Gentamicin sulfate and polymyxin B were from Sigma Chemical Co. (St. Louis, MO). Amikacin and netilmicin were from Bristol-Myers Squibb (New York) and Schering-Plough Corp. (Kenilworth, NJ), respectively.

Radiolabeled reagents. Iodination of urokinase, aprotinin, and aprotinin mutants with ${ }^{125} \mathrm{I}$ was carried out by the chloramine-T method as described (38). The specific activity was $0.5-2.0 \times 10^{6}$ becquerel $(\mathrm{Bq})$ per microgram protein. $\left[{ }^{3} \mathrm{H}\right]$ gentamicin sulfate was a custom synthesized product provided by Dupont NEN Research Products (Brussels, Belgium) and the specific activity was $10^{7} \mathrm{~Bq} / \mu \mathrm{mol}$.

Receptor binding assays. A solid-phase assay previously described $(20,36)$ was used for measuring drug-mediated inhibition of binding of ${ }^{125} \mathrm{I}$-urokinase PAI-1 to $\alpha_{2} \mathrm{MR} / \mathrm{LRP}$ and gp330. Binding of [ ${ }^{3} \mathrm{H}$ ]gentamicin to gp330 was analyzed by equilibrium dialysis experiments. These were performed with a thermostatic arrangement working at $22^{\circ} \mathrm{C}$ (39) in chambers containing $20 \mu$ l solution volume separated by a thin cellulose membrane, type 14.10 (Diachema; Cary LeLocle, Switzerland), with a molecular cut off at $5 \mathrm{kD}$. The left-side compartments contained $\left[{ }^{3} \mathrm{H}\right]$ gentamicin and gp330, with or without unlabeled gentamicin or EDTA. The right-side compartments contained $20 \mu \mathrm{l}$ of buffer alone. After $4 \mathrm{~h}$, equilibrium was established and the radioactivity in the compartments was measured by liquid scintillation counting. The gp330 concentration was measured with the Bio Rad Laboratories Protein Assay (Richmond, CA) based on the method of Bradford (40). All experiments were performed in $140 \mathrm{mM} \mathrm{NaCl}, 10 \mathrm{mM}$ Hepes, 2 $\mathrm{mM} \mathrm{CaCl}_{2}, 1 \mathrm{mM} \mathrm{MgCl}$, $\mathrm{pH} 7.8$.

Binding of aprotinin to rat kidney cortex sections was carried out as described (4). Renal cortical cryosections were obtained from male Wistar rat kidneys fixed by retrograde perfusion through the abdominal aorta with $8 \%$ formaldehyde in $0.1 \mathrm{M}$ sodium cacodylate buffer, $\mathrm{pH}$ 7.2. The cryosections were incubated with ${ }^{125} \mathrm{I}$-aprotinin $\left(4 \times 10^{4} \mathrm{~Bq} /\right.$ $\mathrm{ml}$ ) for $\mathbf{3 0} \mathrm{min}$. For light microscopic autoradiography, the sections were dipped in emulsion (L1; Amersham Corp., Arlington Heights, IL) and exposed for 2-7 d.

Ligand and drug uptake in cultured L2 carcinoma cells. Rat L2 yolk sac carcinoma cells were kindly provided by Dr. U. Wewer, University of Copenhagen, Denmark. The cells were grown in minimum essential medium (MEM) (GIBCO BRL, Life Technologies Ltd., Paisley, United Kingdom) added $10 \%$ FCS. Incubation of L2 cells with ${ }^{125} \mathrm{I}$ labeled proteins was carried out in MEM supplemented with $0.1 \%$ BSA. Degradation of the proteins was measured by precipitation of the incuba- tion medium in $12.5 \%$ TCA. Cell-associated radioactivity was measured by counting the cells after solubilization of the cell layer in $1 \%$ Triton $\mathrm{X}-100$. Electron microscopic autoradiography was carried out on 60 nm uranyl acetate-stained Epon sections of $\mathrm{L} 2$ cells fixed in $1 \%$ glutaraldehyde for $2 \mathrm{~h}$ at $4^{\circ} \mathrm{C}$.

In vivo uptake studies of aprotinin mutants and gentamicin. Female Wistar rats, weighing 175-235 grams were used. An oral dose of $2 \mathrm{ml}$ $\mathrm{H}_{2} \mathrm{O}$ was given before administration of the aprotinin mutants. The mutants were given intravenously as bolus injections into a tail vein using an intravenous catheter. After $3 \mathrm{~h}$, the rats were killed by administration of $\mathrm{CO}_{2}$ into the cage, and the kidneys were removed and stored at $-80^{\circ}$ until analysis. During $\mathrm{CO}_{2}$ administration, the rats emptied the urinary bladder. The metabolism cages used were rinsed with $0.9 \%$ $\mathrm{NaCl}$ to obtain a total urine- $\mathrm{NaCl}$ volume at $10 \mathrm{ml}$.

The levels of aprotinin and mutants in urine, plasma, kidney, and liver homogenates were measured photometrically by using an assay for kallikrein inhibitory activity (37). Before the measurements, the various media were precipitated with acid to remove endogenous inhibitors of kallikrein. Kallikrein was from Sigma Chemical Co. and chromogene substrate S2266 was from Kabi AB (Stockholm, Sweden). Separate standard curves were performed for each mutant in each medium. At least three experiments were carried out with each mutant.

Microinfusion of proximal convoluted tubules of Wistar rats with ${ }^{125} \mathrm{I}$-aprotinin and $\left[{ }^{3} \mathrm{H}\right]$ gentamicin was carried out as described previously (4) for ${ }^{125}$ I-RAP. Male Wistar rat (225 grams) were anesthetized by intraperitonal injection of penthotal sodium $(150 \mathrm{mg} / \mathrm{kg}$ body weight, Abbot, Vedbæk, Denmark) and placed on a thermostatically heated table. After tracheotomy, a catheter was placed in the right jugular vein and the rat was infused with an $0.9 \% \mathrm{NaCl}$ solution at a constant rate a $3.8 \mathrm{ml} / \mathrm{min}$. The left kidney was exposed by a flank incision, placed in a thermostatically heated cup, covered with liquid paraffin, and the ureter was catherized. The perirenal temperature was maintained at $37^{\circ} \mathrm{C}$. Tubules were microinfused with $50 \mathrm{nl}$ of Hepes buffer containing either $\left[{ }^{3} \mathrm{H}\right]$ gentamicin $(5,000 \mathrm{cpm})$ or ${ }^{125} \mathrm{I}$-aprotinin $(2,000 \mathrm{cpm})$ for $2 \mathrm{~min}$. Each tubule was infused twice. In one series of experiments $\left[{ }^{3} \mathrm{H}\right]$ gentamicin was perfused with and without $10 \mu \mathrm{M}$ RAP and in another series of experiments ${ }^{125} \mathrm{I}$-aprotinin was perfused with and without $2 \mathrm{mM}$ gentamicin. To avoid bias, the order of microinfusions was varied in both series. The urine was collected for $\mathbf{4 0} \mathrm{min}$ after each microinfusion, i.e., $2 \times 20$ min collection periods to make sure that urine radioactivity returned to zero before a new microinfusion was started. In both series of experiments the urinary excretion was compared statistically by the method of paired comparisons.

\section{Results}

Inhibition of ligand binding to gp330 and $\alpha_{2} M R / L R P$ by polybasic drugs. Binding of the polybasic drugs to the two negatively charged receptors, gp330 and $\alpha_{2}$ MR/LRP, was initially assayed by measuring their inhibitory potency on binding of ${ }^{125}$ I-urokinase-PAI-1 complex to immobilized receptors. Fig. 1 shows the inhibition profiles of polymyxin B, aprotinin, and three types of aminoglycosides (gentamicin, netilimicin, and amikacin) on ligand binding to gp330 (Fig. $1 A$ ) and $\alpha_{2} \mathrm{MR} /$ LRP (Fig. $1 B$ ). Almost complete inhibition of the binding of ${ }^{125}$ I-urokinase PAI- 1 to both receptors was observed. Polymyxin $\mathrm{B}$ was the most potent inhibitor $\left(\mathrm{IC}_{50}=0.5 \mu \mathrm{M}\right.$ for gp330 and $\mathrm{IC}_{50}=5 \mu \mathrm{M}$ for $\left.\alpha_{2} \mathrm{MR} / \mathrm{LRP}\right)$. Aprotinin had a $\mathrm{IC}_{50}$ at $\sim 4$ $\mu \mathrm{M}$ for both receptors, while the aminoglycosides had different inhibition profiles with higher $\mathrm{IC}_{50}$ values. Gentamicin had the highest potency among the aminoglycosides $\left(\mathrm{IC}_{50}=30-50\right.$ $\mu \mathrm{M})$, while the potency of amikacin was 5-10-fold lower. The antagonizing effect of the drugs was also tested using ${ }^{125}$ I-RAP as a ligand. Similar inhibition profiles were obtained (data not shown) except that only $\sim 80 \%$ of the binding was displaceable 


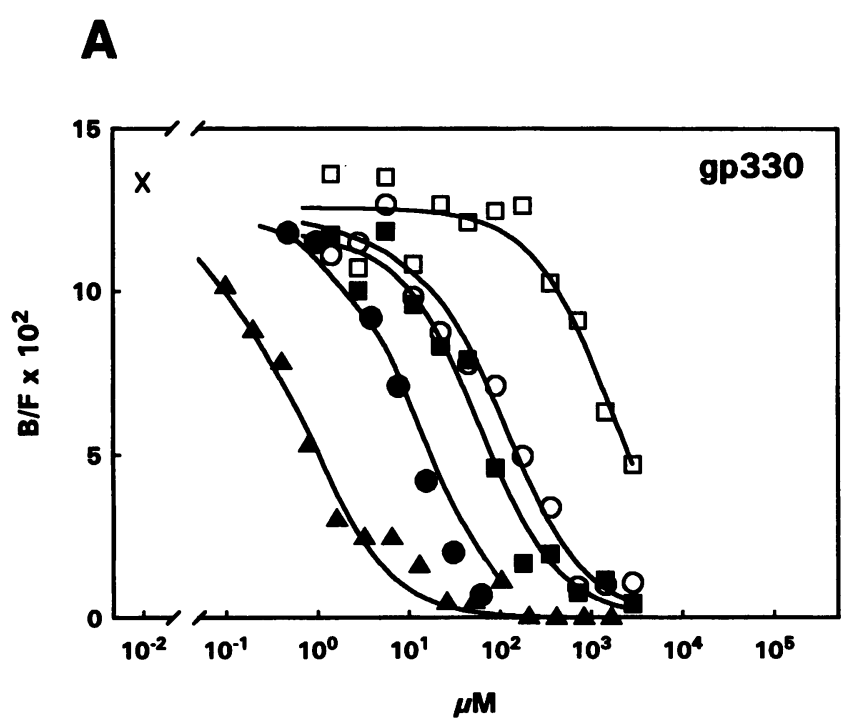

B

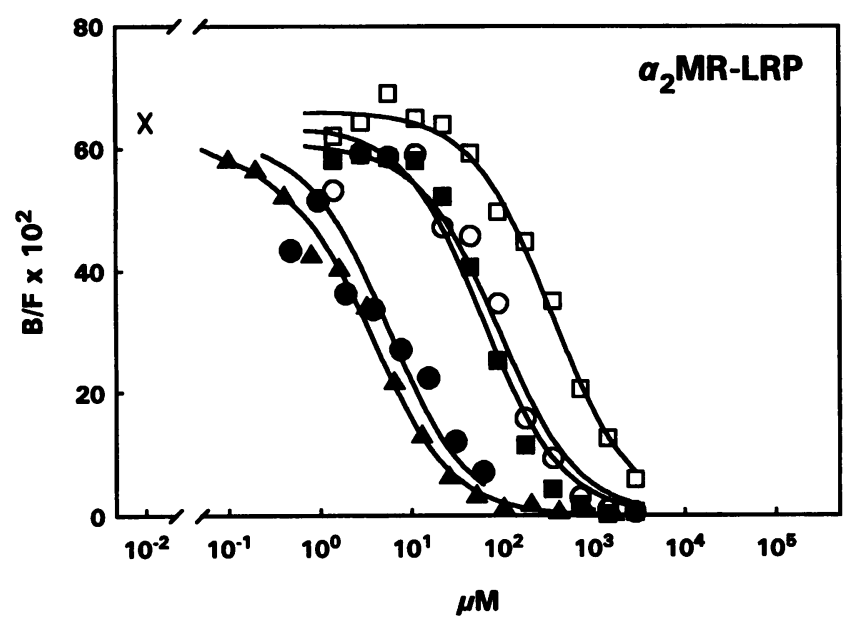

Figure 1. Effect of aprotinin $(\bullet)$, polymyxin B ( $\Delta)$ and the aminoglycosides gentamicin $(\square)$, netilimicin $(O)$ and amikacin $(\square)$ on the binding of ${ }^{125}$ I-urokinase-PAI-1 complexes to purified rabbit gp330 (A) and human $\alpha_{2}$ MR/LRP (B). 20-50 pM receptor protein was immobilized to microtiter wells and binding of $10 \mathrm{pM}^{125} \mathrm{I}$-urokinase-PAI-1 was measured after $16 \mathrm{~h}$ at $4^{\circ} \mathrm{C}$. The ordinates is the bound $(B)$ radioactivity in relation to the free $(F)$ radioactivity. The points are the means of duplicate values after subtraction of nonspecific binding $(<0.5 \%)$. $X$ represents the binding when no antagonist was added.

with aprotinin, probably due to the presence of multiple RAP binding sites in each receptor $(20,41)$.

Renal gp330-mediated binding and endocytosis of aprotinin and mutants. The investigation of gp330 binding and renal handling of aprotinin included a comparative analysis with a panel of recombinant aprotinin mutants with a variety of net charges expressed in $S$. cerevisiae (Table I).

${ }^{125}$ I-aprotinin bound specifically to the proximal tubules epithelium (Fig. 2) as assessed by binding to rat kidney cortex sections and light microscopic autoradiography. The autoradiographic grains representing bound ${ }^{125} \mathrm{I}$-aprotinin were localized over the epithelium of the proximal tubule cells, whereas virtually no grains were observed over distal tubules and collecting
Table I. Primary Sequences, Net Charges, and Denaturation Temperatures of Aprotinin Mutants Expressed in S. cerevisae

\begin{tabular}{llrr}
\hline $\begin{array}{c}\text { ID of } \\
\text { expression } \\
\text { product }\end{array}$ & \multicolumn{1}{c}{ Primary sequence } & $\begin{array}{r}\text { Net } \\
\text { charge }\end{array}$ & $\begin{array}{r}\text { Denaturation } \\
\text { temperature }\end{array}$ \\
\hline & & & ${ }^{\circ} \mathrm{C}$ \\
Aprotinin & $1-58 *$ & 6 & $>100$ \\
KFN 322 & $3-58$ & 5 & 84 \\
KFN 324 & $3-58$, R42S & 4 & 79 \\
KFN 396 & $3-58$, R17A + R42S & 3 & 75 \\
KFN 399 & $3-58$, R17A + I19E + R42S & 2 & 67 \\
KFN 430 & $3-58$, I19E + R42S & 3 & 70 \\
KFN 773 & $3-58$, K15R + R17A + R42S & 3 & 71 \\
KFN 1512 & $1-58$, R1E + K26E + K41E + K46E & -2 & 87 \\
KFN 1514 & 1-58, R1E + R42E + K46E & 0 & 88 \\
KFN 1544 & $1-58$, R42E + K46E & 2 & 98 \\
KFN 1660 & $3-58$, R42S + K46E & 2 & 77 \\
KFN 1661 & $3-58$, R42S + K46A & 3 & 79 \\
KFN 1742 & $3-58$, R42S + R53E & 2 & 71 \\
KFN 1751 & $3-58$, R42E + R53E & 1 & 72 \\
KFN 1755 & $3-58$, R26E + R42S + R53E & 0 & 68 \\
\hline
\end{tabular}

* The 58 amino acid aprotinin sequence: RPDFCLLEPPY TGPCKARII RYFYNAKAGL CQTFVYGGCR KRNNFKSAE DCMRTCGGA

ducts. The distribution of bound aprotinin was similar to the distribution of gp330 $(1,4)$ and bound ${ }^{125}$ I-labeled RAP (4) and urokinase PAI-1 (20). Complete inhibition by RAP and EDTA (Table II) indicated that gp330 accounts for the binding of ${ }^{125} \mathrm{I}$-aprotinin to the cortical sections.

The panel of aprotinin mutants displayed a great variability in inhibitory potency on ${ }^{125} \mathrm{I}$-aprotinin binding to the cortex sections (Fig. 2, Table II) and a similar variability in inhibitory effect on ${ }^{125}$ I-urokinase-PAI-1 binding to purified gp330 (Table III) was observed. In Fig. 2, KFN 322 and KFN 1751 exemplify the different effects of the mutants on ${ }^{125} \mathrm{I}$-aprotinin binding. FN 322 (deletion of amino terminal Arg and Pro) exhibited a strong inhibition whereas virtually no inhibition was seen with KFN 1751 (deletion of amino terminal Arg and Pro plus substitution of $\mathrm{Arg}_{42}$ and $\mathrm{Arg}_{53}$ to Glu ). The complete binding analysis of the of aprotinin mutants (Tables II and III) revealed that several basic amino acids contribute to the binding of aprotinin to gp330 (e.g., $\mathrm{Lys}_{46}$ and $\mathrm{Arg}_{17}$ ) while others (e.g., $\mathrm{Arg}_{1}$ and $\left.\operatorname{Arg}_{42}\right)$ are less important. Furthermore, introduction of acidic residues (e.g., substitution of $\mathrm{Ile}_{19}$ to Glu and $\mathrm{Arg}_{42}$ to Glu) causes a decreased affinity.

To assess the physiological relevance of binding to gp330, the relative gp330-affinity of the mutants were compared with the excretion of intravenously injected mutants in the urine (Table III). As shown in Table III, only $\sim 2 \%$ of injected aprotinin was excreted, whereas injected low affinity mutants with $\mathrm{IC}_{50}>32 \mu \mathrm{M}$ for inhibition of ${ }^{125} \mathrm{I}$-urokinase-PAI-1 binding had a 5- to 25-fold higher excretion in the urine.

The tissue distribution of biologically active aprotinin was estimated as kallikrein-inhibitory activity $3 \mathrm{~h}$ after intravenous administration. The highest accumulation of aprotinin was measured in the kidneys $(43.7 \pm 2.4 \%, n=4)$ and liver $(4.7 \pm 1.0 \%$, $n=4)$. All mutants showed a lower accumulation in kidney and liver, probably due to a decreased receptor affinity (nonin- 

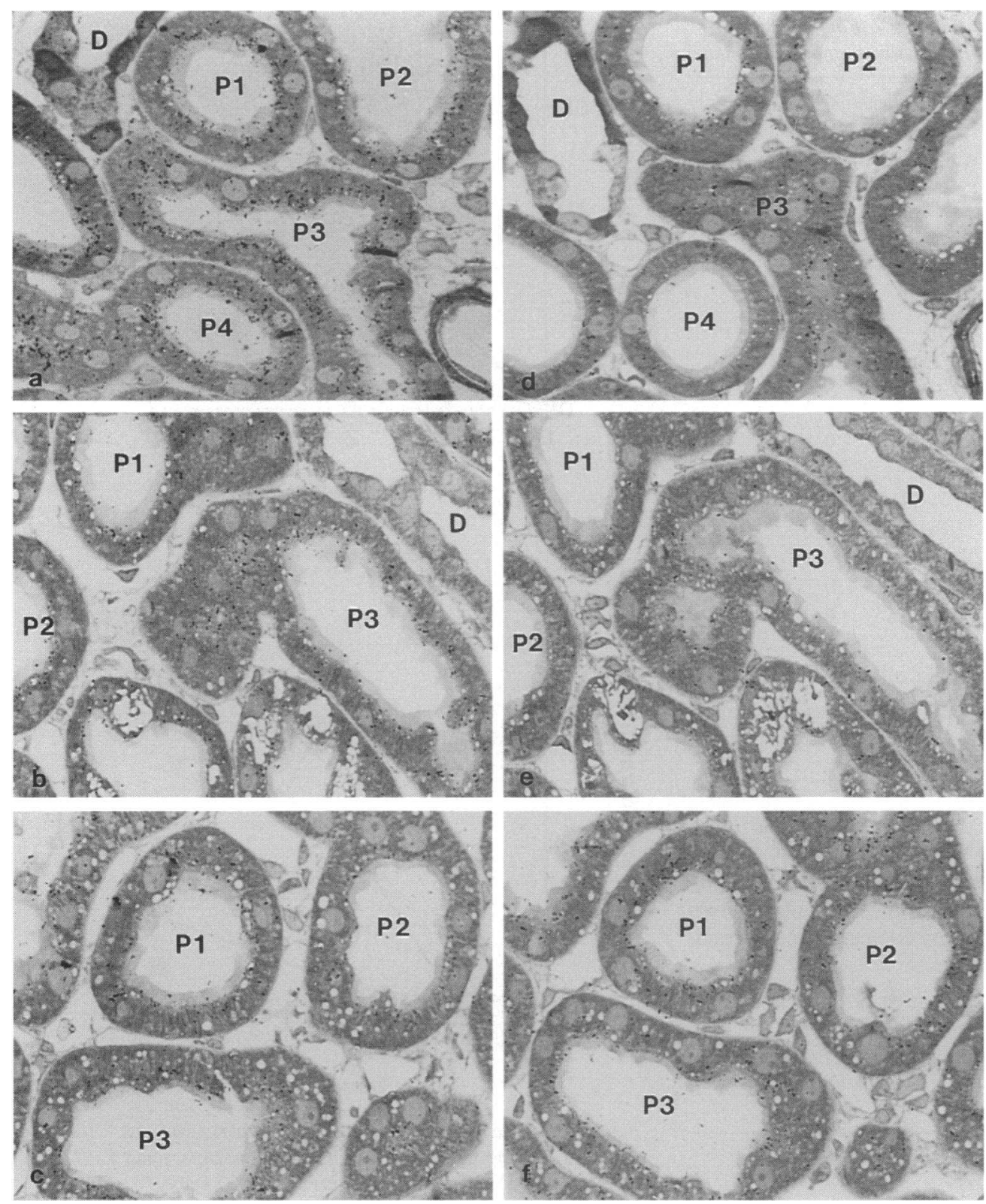

Figure 2. Light microscopic autoradiographs of rat renal cortex sections incubated with ${ }^{125}$ I-aprotinin $(a-c)$ and neighbor sections incubated with ${ }^{125} \mathrm{I}$-aprotinin plus 1 $\mu \mathrm{M}$ aprotinin $(d), \operatorname{KFN} 322(e)$, or KFN $1751(f)$. Autoradiographic grains are localized almost exclusively in the apical part of the proximal tubule cells $(P)$ corresponding to the localization of gp330, whereas collecting ducts and distal tubules $(D)$ are not labeled. Unlabeled aprotinin and KFN 322 virtually abolished binding (compare $a$ to $d$ and $b$ to $e$ ), whereas KFN 1751 had almost no effect on binding (compare $c$ to f). $\mathbf{P} 1, \mathbf{P} 2$, etc. indicates corresponding cross sections in the neighbor sections. Final magnifications 600 .

hibitory mutants) and decreased structural stability. Compared to native aprotinin, the mutants had decreased thermostability (Table I) and stability in kidney lysates (not shown) as measured by the kallikrein-inhibitory activity.

Gp330-mediated endocytosis of aprotinin and two of the mutants was examined in the rat yolk sac carcinoma cell line L2, which expresses gp330 (42) but virtually no $\alpha_{2}$ MR/LRP (43). As shown in Fig. $3,{ }^{125}$ I-aprotinin was rapidly endocytosed in a RAP-inhibitable manner and accumulated in lysosome-like vesicles of L2 cells (Fig. 4). The mutant KFN 324 was also endocytosed in accordance with its binding to gp330 (Tables II and III). However, in contrast to wild-type aprotinin, it was degraded to a much higher extent probably due a decreased structural stability (Table I) which is likely to cause an increased accessibility for cleavage by lysosomal proteases. The mutant KFN 1660, which shows no inhibition of ${ }^{125}$ I-aprotinin binding to gp330, was not endocytosed and no degradation products were detected.
Renal uptake and gp330 binding of gentamicin. Direct binding of $\left[{ }^{3} \mathrm{H}\right]$ gentamicin to purified gp330 was measured by equilibrium dialysis. Equilibrium of the $0.7-\mathrm{kD}\left[{ }^{3} \mathrm{H}\right]$ gentamicin molecules over the membrane was obtained after $4 \mathrm{~h}$ at $22^{\circ} \mathrm{C}$ (data not shown). In the presence of $1 \mu \mathrm{M}$ gp330 in one of the chambers, a significant increase of $\left[{ }^{3} \mathrm{H}\right]$ gentamicin to the protein side was seen (Fig. 5). No significant binding of $\left[{ }^{3} \mathrm{H}\right]-$ gentamicin was seen in the presence of an excess of unlabeled gentamicin. Furthermore, binding of $\left[{ }^{3} \mathrm{H}\right]$ gentamicin to gp330 was reduced with $>50 \%$ when $\mathrm{Ca}^{2+}$ was complexed with EDTA (Fig. 5).

Indirect evidence for binding of gentamicin as well as polymyxin B to cell surface gp330 was obtained by the inhibition of the uptake of ${ }^{125} \mathrm{I}$-aprotinin (Fig. 6) and urokinase-PAI-1 complexes ( $>90 \%$ inhibition by $0.2 \mathrm{mM}$ polymyxin B or 2 $\mathrm{mM}$ gentamicin) in L2 cells. Furthermore, binding of ${ }^{125} \mathrm{I}$-aprotinin to rat cortex sections was completely inhibited by gentamicin (Table II). Experiments with $\left[{ }^{3} \mathrm{H}\right]$ gentamicin directly incu- 
Table II. Inhibition of ${ }^{125}$ I-Aprotinin Binding to Rat Cortex Cryosections by EDTA, RAP, Aprotinin Mutants, and Gentamicin

\begin{tabular}{lc}
\multicolumn{1}{c}{ Inhibitor } & Inhibitory effect* \\
\hline EDTA $(10 \mathrm{mM})$ & +++ \\
RAP $(1 \mu \mathrm{M})$ & +++ \\
Aprotinin & +++ \\
KFN $322^{\ddagger}$ & +++ \\
KFN $324^{\ddagger}$ & ++ \\
KFN $396^{\ddagger}$ & +++ \\
KFN $399^{\ddagger}$ & ++ \\
KFN $430^{\ddagger}$ & +++ \\
KFN $773^{\ddagger}$ & + \\
KFN $1512^{\ddagger}$ & + \\
KFN $1514^{\ddagger}$ & 0 \\
KFN $1544^{\ddagger}$ & + \\
KFN $1660^{\ddagger}$ & + \\
KFN $1661^{\ddagger}$ & + \\
KFN $1742^{\ddagger}$ & + \\
KFN $1751^{\ddagger}$ & 0 \\
KFN $1755^{\ddagger}$ & 0 \\
Gentamicin $(2 \mathrm{mM})$ & +++
\end{tabular}

* Arbitrary units $(+++$, strong inhibition; ++ , moderate inhibition; + , week inhibition; 0 , no inhibition). ${ }^{\ddagger}$ The concentration of aprotinin and mutants was $10 \mu \mathrm{M}$.

bated with monolayer cells were not conclusive. The amount of cell-associated $\left[{ }^{3} \mathrm{H}\right.$ ] gentamicin $(\sim 1 \%)$ was only slightly higher than the nonspecific binding to the well (not shown) probably due to a lower receptor affinity compared to, for example, aprotinin.

Table III. Comparison of the Urinary Excretion of Aprotinin Mutants in Rabbits and Their Inhibitory Potency on Ligand Binding to Purified Rabbit gp330

\begin{tabular}{|c|c|c|}
\hline $\begin{array}{l}\text { Expression } \\
\text { product }\end{array}$ & $\begin{array}{l}\text { Content in urine after } \\
\text { i.v. injection* }\end{array}$ & 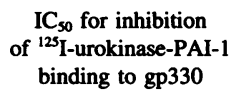 \\
\hline & $\%$ & $\mu M$ \\
\hline Aprotinin & $2.2 \pm 0.3$ & 4 \\
\hline KFN 322 & $1.3 \pm 1.5$ & 4 \\
\hline KFN 324 & $0.8 \pm 0.3$ & 4 \\
\hline KFN 396 & $2.7 \pm 1.0$ & 16 \\
\hline KFN 399 & $2.6 \pm 1.8$ & 16 \\
\hline KFN 430 & $2.0 \pm 0.3$ & 16 \\
\hline KFN 773 & $9.0 \pm 9.3$ & 8 \\
\hline KFN 1512 & $50.7 \pm 12.8$ & $>32$ \\
\hline KFN 1514 & $35.9 \pm 0.9$ & $>32$ \\
\hline KFN 1544 & $41.7 \pm 8.6$ & $>32$ \\
\hline KFN 1660 & $22.9 \pm 4.6$ & $>32$ \\
\hline KFN 1661 & $17.8 \pm 3.6$ & $>32$ \\
\hline KFN 1742 & $11.8 \pm 2.3$ & 16 \\
\hline KFN 1751 & $10.6 \pm 4.1$ & $>32$ \\
\hline KFN 1755 & $10.4 \pm 8.2$ & 32 \\
\hline
\end{tabular}

* The content of aprotinin mutant in collected rabbit urine was measured $3 \mathrm{~h}$ after i.v. administration. $n=2-5$.
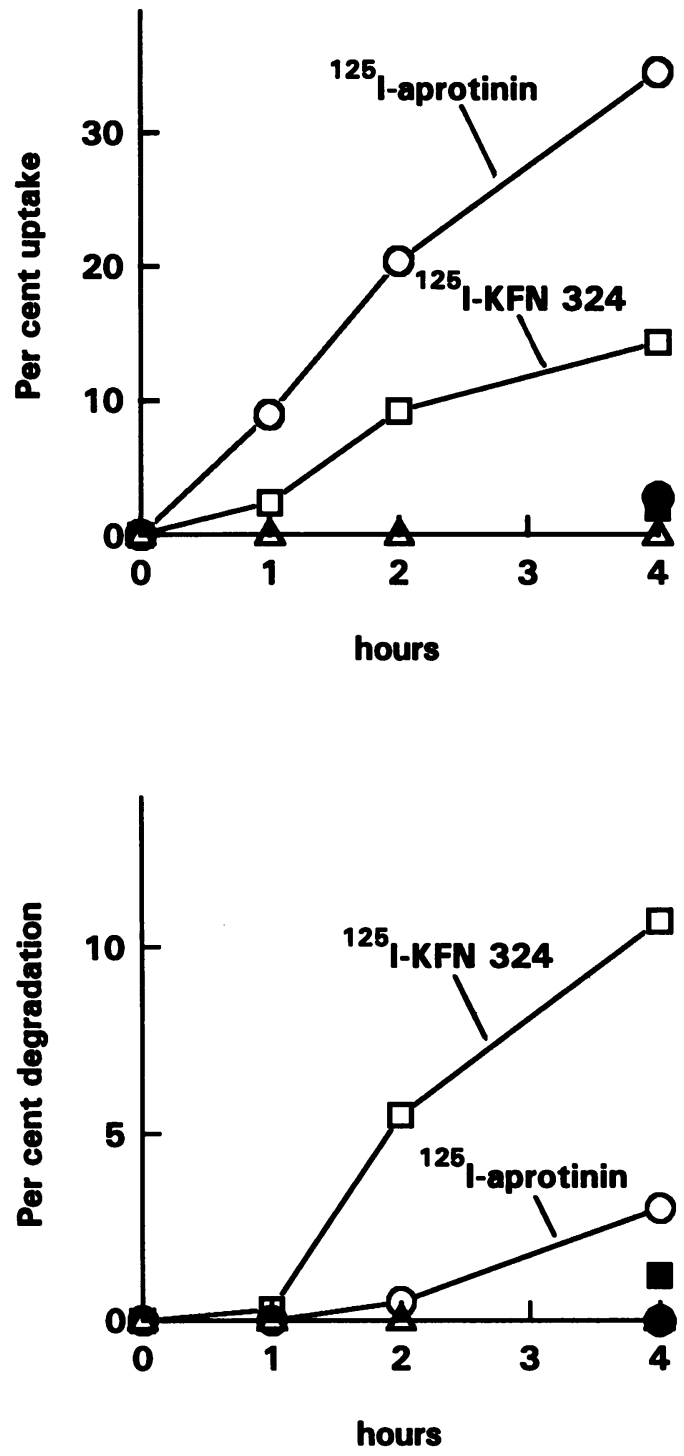

Figure 3. Uptake (top) and degradation (bottom) of $0.5 \mathrm{nM}^{125}$ I-labeled aprotinin (O) and the aprotinin mutants KFN 324 (口) and KFN 1660 $(\Delta)$ in cultured monolayers of rat carcinoma $L 2$ cells. The cellular uptake of the radiolabels as presented in the top panel is the sum of cell-associated and trichloroacetic acid-soluble radioactivity. The trichloroacetic acid-soluble radioactivity representing degraded radiolabel is presented separately in the bottom panel. The filled symbols represent the values when $200 \mathrm{nM}$ RAP was present in the medium. All values are the means of duplicate values.

Microinfusions in vivo of single rat proximal tubules with $\left[{ }^{3} \mathrm{H}\right]$ gentamicin revealed a high uptake of the injected radioligand as assessed by light microscopic autoradiography (Fig. 7) and by counting the excretion of radioactivity in the urine as an inverse measurement. In 15 experiments, 38.2\% (15.6$70.3 \%$ ) of the injected dose was collected in the urine (Table IV). The variation in the excretions display undoubtedly the different length of the proximal tubules in the distal direction of the injection site. Therefore, to analyze the effect of the gp330 inhibitor, RAP, each of the 15 tubules were perfused twice through the same injection site, once with $\left[{ }^{3} \mathrm{H}\right]$ gentamicin alone, and in another perfusion with the addition of $10 \mu \mathrm{M}$ RAP. In the presence of RAP, the excretion was increased to 


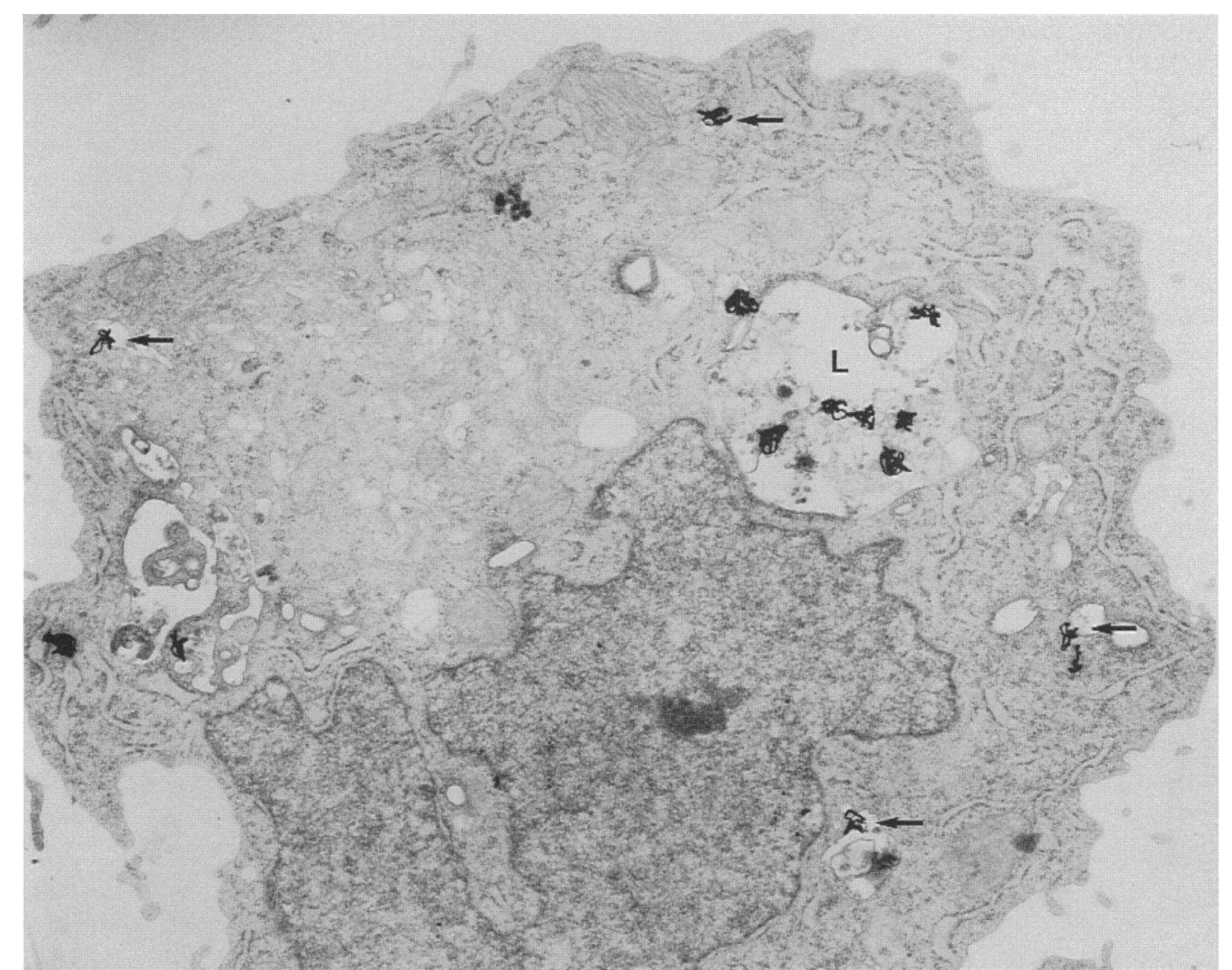

Figure 4. Electron microscopic autoradiograph of L2 carcinoma cells incubated for $2 \mathrm{~h}$ at $37^{\circ} \mathrm{C}$ with $10 \mathrm{nM}^{125} \mathrm{I}$-aprotinin. Autoradiographic grains are seen over vesicles (arrows) and a lysosome/ multivesicular endosome $(L)$. Final magnification 12,500 .
$46.2 \%(21.1-81.0 \%)$. A paired comparison revealed that the increase in urinary excretion of $\left[{ }^{3} \mathrm{H}\right]$ gentamicin was significant $(P<0.01)$

Unlabeled gentamicin had a strong effect on the tubular uptake of ${ }^{125} \mathrm{I}$-aprotinin. Urinary excretion of microinjected ${ }^{125} \mathrm{I}$ aprotinin was $35.2 \%(30.2-37.7 \%)$ of the injected dose, whereas the presence of $2 \mathrm{mM}$ gentamicin increased the excretion to $84.7 \%(57.7-97.4 \%$ ) (Table V). The increase in urinary excretion was highly significant $(P<0.01)$.

\section{Discussion}

In the present report we have provided evidence that epithelial gp330 is a receptor for three types of polybasic drugs (aprotinin, aminoglycosides, and polymyxin B) used in human therapy. The data also show an antagonizing effect of the drugs on ligand binding to the homologous receptor, $\alpha_{2}$ MR/LRP. However, the rapid filtration of the drugs in the glomeruli suggests only a minor uptake in $\alpha_{2} \mathrm{MR} / \mathrm{LRP}$-bearing cells facing the circulation. Accordingly, we observed that $44 \%$ of intravenously injected aprotinin was recovered in the kidney after $3 \mathrm{~h}$ while the content in the liver was 10 -fold lower.

On their way through the kidney proximal tubules, filtered molecules are exposed to a high density of surface-expressed gp330 (1, 7). SDS-PAGE of whole cortex (4) has shown that gp330 accounts for a substantial part, maybe several percent of the total mass of apical membrane protein. The high density of gp330 combined with the length of tubules and concentration of the fluid suggest a high number of collisions between gp330 and filtered molecules. On this basis, gp330 might account for the renal uptake of a number of basic molecules with low affinity charge interactions with gp330. Previous studies have shown that cationic proteins are reabsorbed much more efficiently than anionic proteins (44-46).

The mechanism for uptake of polybasic drugs, in particular aminoglycosides, has previously been studied by several groups. In agreement with our data, Just et al. (30) found that aminoglycosides compete for the binding of aprotinin to isolated renal brush border membrane and a common type of binding site for the two drugs was proposed. Using autoradiographic techniques $(24,28)$ and an immunocytochemical approach $(26)$, gentamicin has been shown to bind to the apical membrane in the proximal tubule, concentrate in coated pits followed by uptake into endocytic compartments. No membrane receptor has so far been shown to be involved in this binding and uptake. Sastrasinh et al. (47) showed binding of aminoglycosides to acidic phospholipids (25). The $K_{\mathrm{d}}$ for binding of gentamicin to phosphatidylinositol is $170 \mu \mathrm{M}(48)$, which is a lower affinity compared to the apparent affinity for gp330 (half maximal inhibition of ${ }^{125} \mathrm{I}$-urokinase-PAI-1 binding at $50 \mu \mathrm{M}$ gentamicin). However, the receptor affinity of gentamicin and the other polybasic drugs are lower compared to endogenous gp330 ligands, which have $K_{\mathrm{d}}$ 's in the nanomolar range (11). Accordingly, the solid phase ${ }^{125}$ I-urokinase-PAI-1 binding assay in Fig. 1 with a limited amount of receptors immobilized in microtiter wells, was not suitable for measuring direct binding of radiolabeled drugs.

Phospholipids are undoubtedly more widely distributed on the epithelial surface compared to gp330, which main membrane location is in coated pits (1). Initial binding to acidic phospholipids and subsequent delivery to gp 330 might therefore be the principal route for receptor-mediated uptake of aminoglycosides (Fig. 8). This model is consistent with the previous autoradiographic studies of aminoglycoside uptake in the kidney $(24,28)$ and explains the weak inhibition by RAP on the uptake 


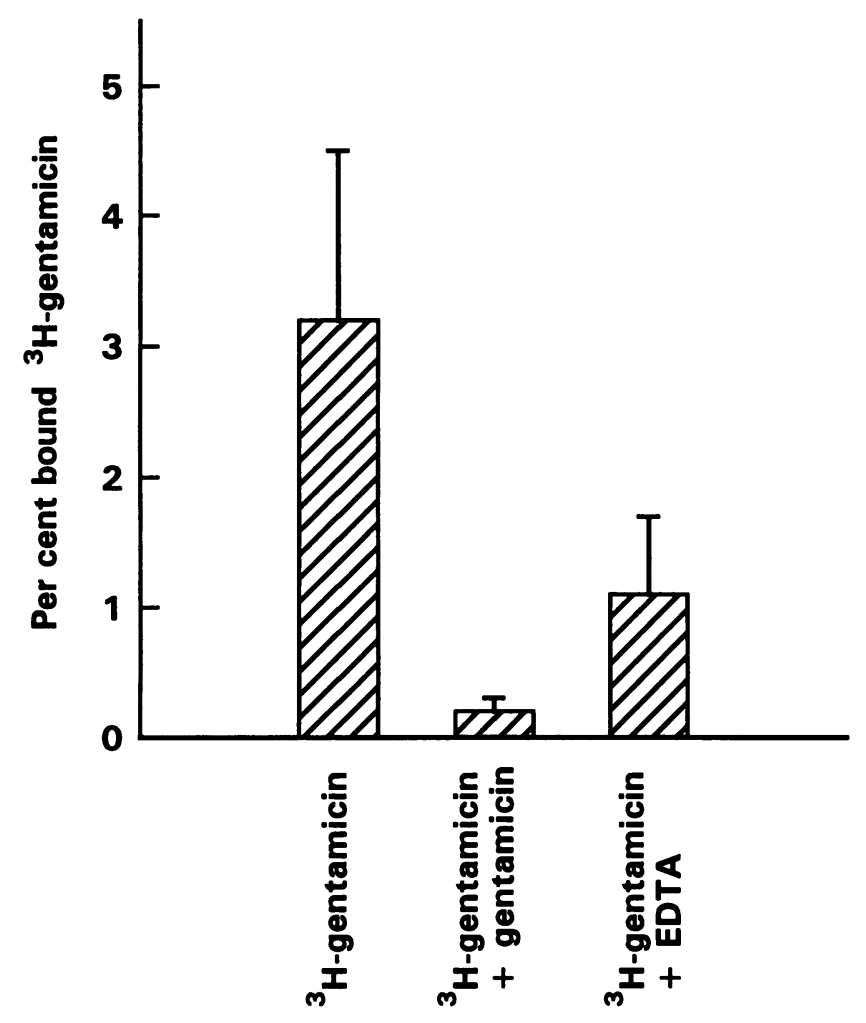

Figure 5. Binding of $\left[{ }^{3} \mathrm{H}\right]$ gentamicin to purified solubilized rabbit gp330 as measured by equilibrium dialysis. The dialysis experiments were performed in $140 \mathrm{mM} \mathrm{NaCl}, 10 \mathrm{mM}$ Hepes, $2 \mathrm{mM} \mathrm{CaCl}_{2}, 1 \mathrm{mM}$ $\mathrm{MgCl}_{2}, \mathrm{pH} 7.8$ with $1 \mu \mathrm{M}$ gp330 incubated with $0.7 \mathrm{nM}\left[{ }^{3} \mathrm{H}\right]$ gentamicin alone, with $2.3 \mathrm{mM}$ gentamicin, and with $20 \mathrm{mM}$ EDTA as indicated. The binding was measured at equilibrium of the tracer $\left(4 \mathrm{~h}\right.$ at $\left.22^{\circ} \mathrm{C}\right)$. The values are binding $( \pm 1$ SD) estimated on difference in radioactivity across the membrane. The figure represents one of three similar experiments. Each experiment was done in triplicate.

of $\left[{ }^{3} \mathrm{H}\right]$ gentamicin in the microinfused rat tubules. A similar mechanism for uptake has been shown for the uptake of urokinase-PAI-1 and lipoprotein lipase via $\alpha_{2}$ MR/LRP. Both ligands

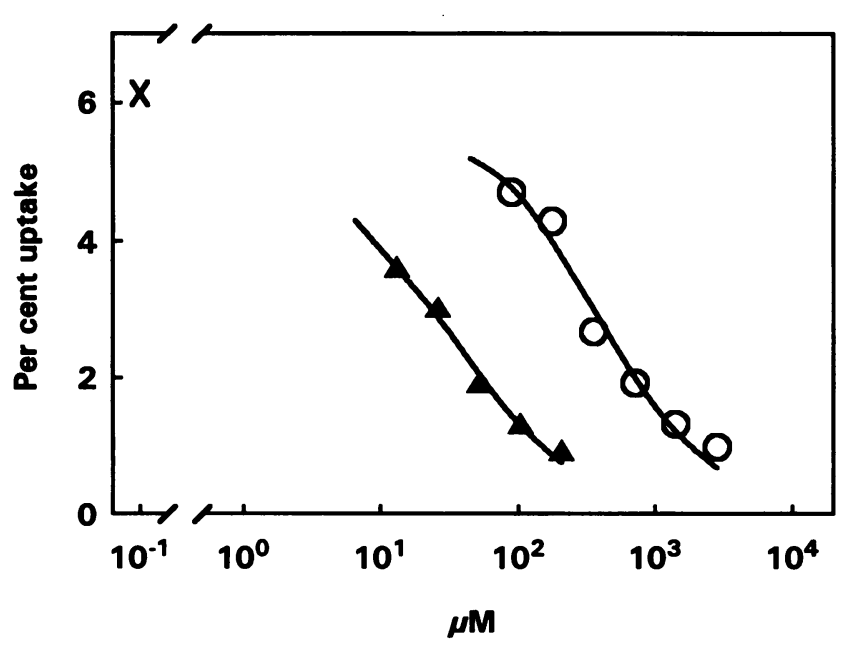

Figure 6. Effect of gentamicin $(\mathrm{O})$ and polymyxin B ( $\triangle)$ on the uptake of ${ }^{125} \mathrm{I}$-aprotinin in L2 carcinoma cells. The cell-associated radioactivity was measured $1 \mathrm{~h}$ after incubation with radiolabel and inhibitor. The values are the means of triplicates.

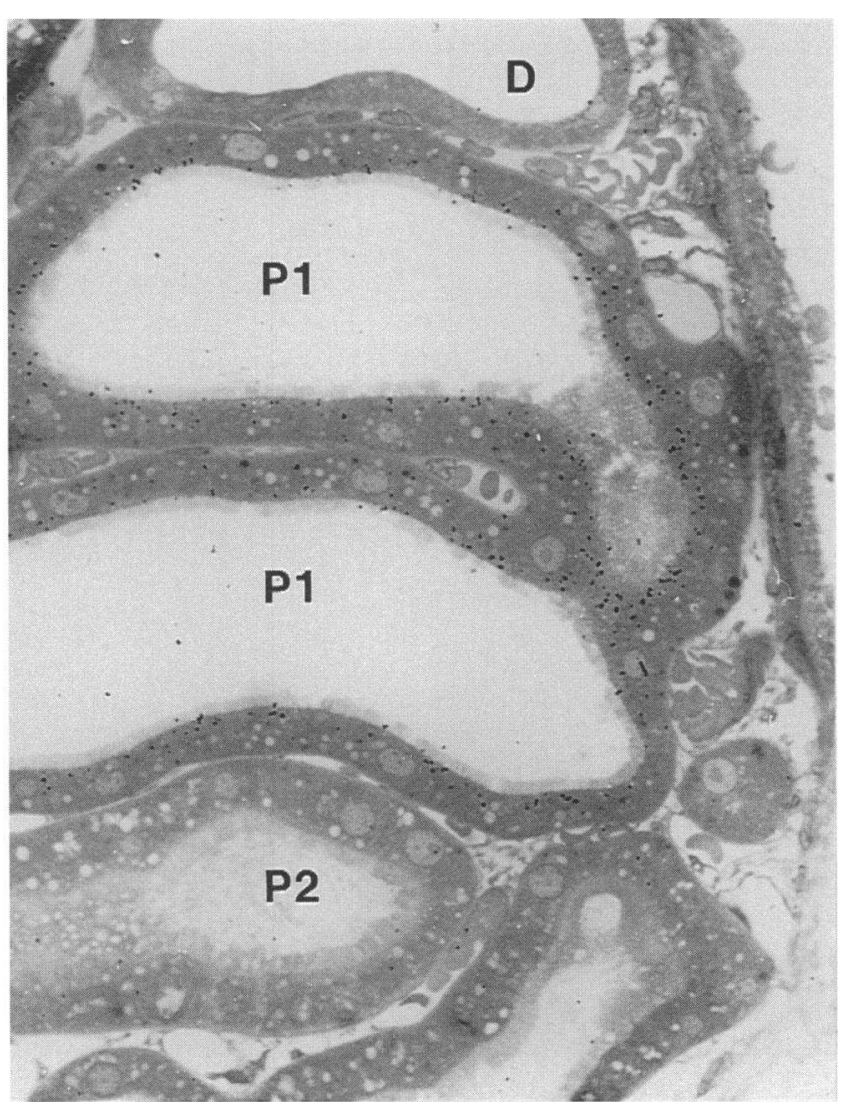

Figure 7. Light microscopic autoradiography of $\left[{ }^{3} \mathrm{H}\right]$ gentamicin microinfused rat proximal tubule fixed $5 \mathrm{~min}$ after microinfusion. Autoradiographic grains are seen exclusively over the microinfused tubule $(P I)$ and not over distal tubules $(D)$. No labeling is seen over noninfused proximal tubules $(P 2)$ or distal tubules $(D)$. Final magnification 625.

bind to nonendocytic membrane components (urokinase receptor and proteoglycans, respectively) but are subsequently bound and endocytosed via $\alpha_{2} \operatorname{MR} / \operatorname{LRP}(36,49,50)$. The hypothesis of a direct connection between gp330-mediated endocytosis of aminoglycosides and their nephrotoxic effect is supported by the fact, that the nephrotoxic effects occurs primarily in the S1 and S2 segments, the same part of the nephron as gp330 preferentially is expressed (51). Furthermore, the apparent gp330 affinities of the aminoglycosides are in the order of gentamicin, netilmicin, and kanamicin, which agrees with their number of dissociable amino groups and nephrotoxic potential (25).

Previous studies have shown uptake, lysosomal accumulation, and toxic effect of aminoglycosides in other cell types as fibroblasts (52), retinal pigment epithelium (53), and cochlea $(22,54)$. Fibroblasts have a high expression of $\alpha_{2}$ MR/LRP $(14,55)$ whereas retinal pigment cells $(8)$ and the inner ear epithelium express gp330 (9). Future studies should in particular explore the role of cochlear gp330 for the uptake of aminoglycosides, lysosomal accumulation, and subsequent ototoxic effects.

The polybasic nature of the drugs suggests charge interactions to be essential for the binding to gp330 and $\alpha_{2}$ MR/LRP. By site-directed mutagenesis of the $6.5-\mathrm{kD}$ Kunitz-type proteinase inhibitor, aprotinin, we demonstrate the importance of basic amino acids for the binding of this protein to gp330. Further- 
Table IV. Effect of RAP on the Renal Uptake of $\left[{ }^{3} \mathrm{H}\right]$ Gentamicin Microinfused In Vivo into Single Rat Proximal Tubules

\begin{tabular}{ccc}
\hline Experiment No. & $\begin{array}{c}\text { Percentage in urine } \\
(- \text { RAP })\end{array}$ & $\begin{array}{c}\text { Percentage in urine } \\
\text { (+RAP) }\end{array}$ \\
\hline 1 & 24.7 & 47.1 \\
2 & 35.4 & 47.3 \\
3 & 41.3 & 50.2 \\
4 & 22.0 & 33.8 \\
5 & 15.7 & 21.1 \\
6 & 47.5 & 50.8 \\
7 & 50.2 & 35.8 \\
8 & 42.0 & 53.2 \\
9 & 56.4 & 58.3 \\
10 & 23.6 & 32.9 \\
11 & 15.7 & 18.2 \\
12 & 16.6 & 21.1 \\
13 & 63.7 & 70.0 \\
14 & 70.3 & 72.0 \\
15 & 50.5 & 81.5 \\
Mean $(n=15)$ & 38.2 & 46.2 \\
& & \\
\hline
\end{tabular}

The values in columns 2 and 3 display the percentages of injected dose $(5,000 \mathrm{cpm})$ collected in the urine for $40 \mathrm{~min}$. Each of 15 tubules was injected with and without $10 \mu \mathrm{M}$ RAP. In experiment $2,3,4,6,8,10$, 11 , and 15, injection with RAP was carried out before the perfusion without RAP and in the rest of the experiments the order was reversed. The urinary content of $\left[{ }^{3} \mathrm{H}\right]$ gentamicin was significantly higher when RAP was present in the injection fluid $(P<0.01$ by the method of paired comparison).

more, our data show that basic residues are essential for renal uptake that correlated with the mutants affinity for purified gp330. Interestingly, another Kunitz-type proteinase inhibitor, the tissue factor pathway inhibitor (TFPI), has very recently been suggested to bind to $\alpha_{2}$ MR/LRP (56) and the authors point on gp330 as the receptor responsible for the kidney clearance of TFPI. It is unsettled whether other proteins with Kunitz

Table V. Effect of Gentamicin on the Renal Uptake of ${ }^{125}$ I-Aprotinin Microinfused In Vivo into Single Rat Proximal Tubules

\begin{tabular}{ccc}
\hline Experiment No. & $\begin{array}{c}\text { Percentage in urine } \\
\text { (-gentamicin) }\end{array}$ & $\begin{array}{c}\text { Percentage in urine } \\
\text { (+gentamicin) }\end{array}$ \\
\hline 1 & 30.2 & 99.4 \\
2 & 39.4 & 92.3 \\
3 & 37.7 & 57.3 \\
4 & 33.6 & 89.9 \\
Mean $(n=4)$ & 35.2 & 84.7 \\
\hline
\end{tabular}

The values in columns 2 and 3 display the percentage of injected dose $(2,000 \mathrm{cpm})$ collected in the urine for $40 \mathrm{~min}$. Each of four tubules was infused with and without $2 \mathrm{mM}$ gentamicin. In experiments 3 and 4 injection with gentamicin was carried out before the perfusion without gentamicin and in the two other experiments the order was reversed as described in Methods. The urinary content of ${ }^{125}$ I-aprotinin was significantly higher when gentamicin was present in the injection fluid $(P$ $<0.01$ by the method of paired comparison).

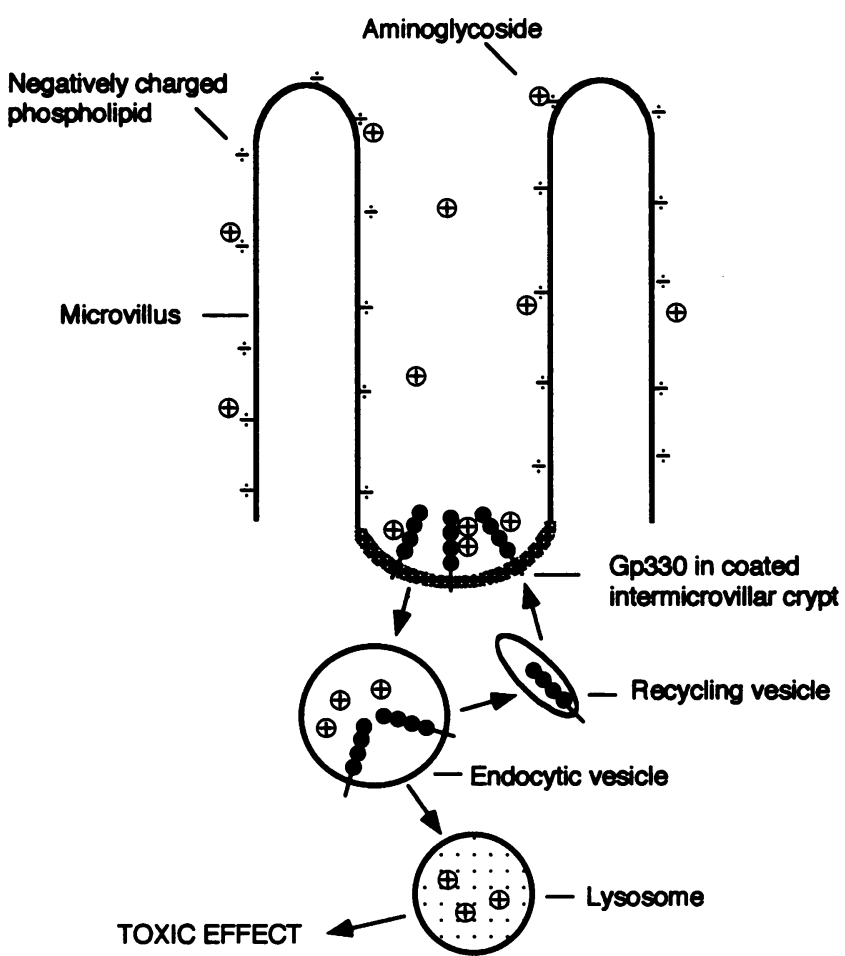

Figure 8. A possible model for interaction of aminoglycosides with the renal proximal tubule epithelium. Aminoglycosides are concentrated in the intravillar space by binding to negatively charged phospholipids on the cell surface. Subsequent delivery to negatively charged gp330 in the intravillar crypts leads to an endocytic uptake and accumulation of the aminoglycoside drugs in lysosomes, where the polybasic particles exert their toxic effects on the cells.

domains, e.g., amyloid precursor protein are processed via gp330 or $\alpha_{2}$ MR/LRP. However, the present data do not suggest that the common feature of having Kunitz domains is the reason that aprotinin and TFPI apparently bind to the same receptors, since two of the basic aprotinin residues $\left(\mathrm{Lys}_{46}\right.$ and $\mathrm{Arg}_{17}$ ) essential for receptor binding are located outside the Kunitz domain of aprotinin (32).

Polymyxin B was the drug with the highest inhibitory potential on ligand binding to gp330 and $\alpha_{2}$ MR/LRP and it seems likely that gp330-mediated endocytosis is associated with its nephro- and ototoxic effect $(33,34)$. The binding sites for polymyxin $B$ in the proximal tubules and the cochlear epithelium have not previously been characterized but other studies have shown specific $\mathrm{Ca}^{2+}$-dependent uptake of polymyxin $\mathrm{B}$ in macrophages, hepatocytes, fibroblasts, and smooth muscle cells via a receptor-mediated pathway not dependent of the LDLreceptor or asialoglycoprotein receptor (57-59). $\alpha_{2}$ MR/LRP is highly expressed in these cell types (14).

In conclusion we have shown a novel role of gp330 as a drug receptor and provided new insight into the molecular mechanism for uptake of polybasic drugs. In view of the severe therapeutic side effects in the kidney and ear caused by lysosomal accumulation of polybasic drugs, in particular aminoglycosides, it would be interesting to explore the possibility of a selective inhibition of receptor-mediated drug uptake not disturbing the antibiotic effect.

\section{Acknowledgments}

Thanks to Kirsten Lassen, Hanne Sidelman and Inger B. Kristoffersen for excellent technical assistance. 
The present study was financially supported by the Danish Medical Research Council, the Novo Nordisk Foundation, the Carlsberg Research Foundation, the Foundation of the Advancement of Medical Science, the Danish Medical Society Research Foundation, and the Danish Biomembrane Center.

\section{References}

1. Kerjaschki, D., and M. G. Farquhar, M. G. 1982. The pathogenic antigen of Heymann nephritis is a membrane glycoprotein of the renal proximal tubule brush border. Proc. Natl. Acad. Sci. USA. 79:5557-5561.

2. Saito, A., S. Pietromonaco, A. K.-C. Loo, and M. G. Farquhar. 1994. Complete cloning and sequencing of rat gp330/'megalin', a distinctive member of the low density lipoprotein receptor gene family. Proc. Natl. Acad. Sci. USA. 91:9725-9729.

3. Makker, S. P., and A. K. Singh. 1984. Characterization of the antigen (gp600) of Heymann Nephritis. Lab. Invest. 50:287-293.

4. Christensen, E. I., J. Gliemann, and S. K. Moestrup. 1992. Renal tubule glycoprotein 330 is a calcium-binding receptor mediating endocytosis of protein. J. Histochem. Cytochem. 40:1481-1490.

5. Willnow, T. E., J. L. Goldstein, K. Orth, M. S. Brown, and J. Herz. 1992. Low density lipoprotein receptor-related protein and gp330 bind similar ligands, including plasminogen activator-inhibitor complexes and lactoferrin, an inhibitor of chylomicron remnant clearance. J. Biol. Chem. 267:26172-26180.

6. Kounnas, M. Z., W. S. Argraves, and D. K. Strickland. 1992. The 39$\mathrm{kDa}$ receptor-associated protein interacts with two members of the low density lipoprotein receptor family, $\alpha_{2}$-macroglobulin receptor and glycoprotein $330 . J$. Biol. Chem. 267:21162-21166.

7. Chatelet, F., E. Brianti, P. Ronco, J. Roland, and P. Verroust. 1986. Ultrastructural localization by monoclonal antibodies of brush border antigens expressed by glomeruli. II. Extrarenal distribution. Am. J. Pathol. 122:512-519.

8. Zheng, G., D. R. Bachinsky, I. Stamekovic, D. K. Strickland, D. Brown, G. Andres, and R. T. McCluskey. 1994. Organ distribuion in rats of two members of the low density lipoprotein receptor gene family, gp330 and LRP/ $\alpha 2 \mathrm{MR}$, and the receptor-associated protein (RAP). J. Histochem. Cytochem. 42:531-542.

9. Kounnas, M. Z., C. C. Haudenschild, D. K. Strickland, and W. S. Argraves 1994. Immunological localization of glycoprotein 330 , low density lipoprotein receptor-related protein and $39 \mathrm{kDa}$ receptor-associated protein in mouse embryonic tissues In Vivo (Athens). 8:343-351.

10. Raychowdhury, R., J. L. Niles, R. T. McCluskey, and J. A. Smith. 1989. Autoimmune target in Heymann nephritis is a glycoprotein with homology to the LDL receptor. Science (Wash. DC). 244:1163-1165.

11. Moestrup, S. K. 1994. The $\alpha_{2}$-macroglobulin receptor and glycoprotein 330. Two giant receptors mediating endocytosis of multiple ligands. Biochim Biophys. Acta. 1197:197-213.

12. Krieger, M. and J. Herz. 1994. Structures and functions of multiligand receptors: Macrophage scavenger receptors and LDL receptor-related protein (LRP). Annu. Rev. Biochem. 63:601-637.

13. Makker, S. P. 1993. Analysis of glomeruli-eluted gp330 autoantibodies and of gp330 antigen of Heymann Nephritis. J. Immunol. 151:6500-6508.

14. Moestrup, S. K., J. Gliemann, and G. Pallesen. 1992. Distribution of the $\alpha_{2}$-macroglobulin receptor/low density lipoprotein receptor-related protein in human tissues. Cell Tissue Res. 269:375-382.

15. Moestrup, S. K., K. Kaltoft, L. Sottrup-Jensen, and J. Gliemann. 1990 The human $\alpha_{2}$-macroglobulin receptor contains high affinity calcium binding sites important for receptor conformation and ligand recognition. J. Biol. Chem 265:12623-12628.

16. Orlando, R. A., D. Kerjaschki, H. Kurihara, D. Biemesderfer, and M. G. Farquhar. 1992. Gp330 associates with a 44-kDa protein in the rat kidney to form the Heymann nephritis antigenic complex. Proc. Natl. Acad. Sci. USA. 89:66986702 .

17. Kanalas, J. J., and S. P. Makker. 1991. Identification of rat Heymann Nephritis autoantigen as a receptor site for plasminogen. J. Biol. Chem 266:10825-10829.

18. Moestrup, S. K., T. L. Holtet, M. Etzerodt, H. C. Thøgersen, A. Nykjær, P. A. Andreasen, H. H. Rasmussen, L. Sottrup-Jensen, and J. Gliemann. 1993 $\alpha_{2}$-macroglobulin proteinase complexes, plasminogen activator inhibitor type-1plasminogen activator complexes and receptor-associated protein bind to a region of the $\alpha_{2}$-macroglobulin receptor containing a cluster of eight complement-type repeats. J. Biol. Chem. 268:13691-13696.

19. Willnow, T. E., K. Orth, and J. Herz. 1994. Molecular dissection of ligand binding sites on the low density lipoprotein receptor-related protein. J. Biol. Chem. 269:15827-15837.

20. Moestrup, S. K., S. Nielsen, P. A. Andreasen, K. E. Jørgensen, A. Nykjær, H. Røigaard, J. Gliemann, and E. I. Christensen. 1993. Epithelial glycoprotein330 mediates endocytosis of plasminogen activator-plasminogen activator type- 1 complexes. J. Biol. Chem. 268:16564-16570.

21. Lundgren, S., G. Hjälm, P. Hellman, B. Ek, C. Juhlin, J. Rastad, L.
Klareskog, G. Åkerstrøm, and L. Rask. 1994. A protein involved in the calcium sensing of the human parathyroid, placenta and kidney tubule cells belongs to the LDL-receptor protein superfamily. Exp. Cell Res. 212:344-350.

22. de Groot, J. C., F. Meeuwsen, W. E. Ruizendaal, and J. E. Veldman. 1990. Ultrastructural localization of gentamicin in clochlea. Hear. Res. 50:3542.

23. Morin, J. P., G. Viotte, A. Vanderwalle, F. Vanhoof, P. Tulkens, and J. P. Fillastre. 1988. Gentamicin-induced nephrotoxicity: a cell biology approach Kidney Int. 18:583-590.

24. Silverblatt, F. J., and C. Kuehn. 1983. Autoradiography of gentamicin uptake by the rat proximal tubule cell. Lab. Invest. 48:212-223.

25. Humes, H. D. 1988. Aminoglycoside nephrotoxicity. Kidney Int. 22:900911

26. Molitoris, B. A., C. Meyer, R. Dahl, and A. Geerdes. 1993. Mechanism of ischemia-enhanced aminoglycosides binding and uptake by proximale tubule cells. Am. J. Physiol. 264:F907-F916.

27. Houghton, D. C., M. Hartnett, M. Campbell-Boswell, G. Porter, and W. Bennet. 1976. Chronic gentamicin nephrotoxicity. Am. J. Pathol. 82:589-612.

28. Wedeen, R. P., V. Batuman, C. Cheeks, E. Marquet, and H. Sobel. 1983. Transport of gentamicin in the rat proximal tubule. Lab. Invest. 48:212-223.

29. Tran-Ba-Huy, P., P. Bernard, and J. Schacht. 1986. Kinetics of gentamicin uptake and release in the rat. Comparison of inner ear tissues and fluids with other organs. J. Clin. Invest. 77:1492-500.

30. Just, M., G. Erdmann, and E. Habermann. 1977. The renal handling of polybasic drugs. 1. Gentamicin and aprotinin in intact animals. Arch. Pharmacol. 300:57-66.

31. Just, M. and E. Habermann. 1977. The renal handling of polybasic drugs 2. In vitro studies with brush border and lysosomal fractions. Arch. Pharmacol. 300:67-76.

32. Creighton, T. E. 1975. The two disulphide intermediates and the folding pathway of reduced pancreatic trypsin inhibitor. J. Mol. Biol. 95:167-199.

33. Bergen, T., and J. Fuglsang. 1982. Polymyxin antibiotics. Antibiot. Chemother. (Wash. DC). 31:119-144.

34. Sande, M. A., and G. L. Mandell. 1990. Antimicrobial agents. In Goodman and Gilmann's The Pharmalogical Basis of Therapeutics. A. G. Gilman, T. W. Rall, A. S. Nies, and P. Taylor editors, Pergamon Press Inc., New York. 1117 1148.

35. Morrison, D. C. and D. M. Jacobs. 1978. Binding of polymyxin B to lipid A portion of bacterial lipopolysaccharides. Immunochemistry. 3:813-818.

36. Nykjær, A., C. M. Petersen, B. Møller, P. H. Jensen, S. K. Moestrup T. L. Holtet, M. Etzerodt, H. C. Thøgersen, M. Munch, P. A. Andreasen, and J. Gliemann. 1992. Purified $\alpha_{2}$-macroglobulin receptor/LDL receptor-related protein binds urokinase-plasminogen activator inhibitor type-1 complex. Evidence that the $\alpha_{2}$-macroglobulin receptor mediates cellular degradation of urokinase receptorbound complexes. J. Biol. Chem. 267:14543-14546.

37. Norris, K., F. Norris, S. E. Bjørn, I. Diers, and L. C. Petersen. 1990. Aprotinin and aprotinin analogues expression in yeast. Biol. Chem. Hoppe-Seyler. 371:37-42.

38. Gliemann, J. and O. Davidsen. 1986. Characterization of receptors for $\alpha_{2-}$ macroglobulin complexes in rat hepatocytes. Biochem. Biophys. Acta. 885:4957.

39. Brodersen, R., S. Andersen, C. Jacobsen, O. Sønderskov, F. Ebbesen, W. J. Cashore, and S. Larsen. 1982. Determination of the reserve albumin-equivalent for ligand binding, probing two distinct binding functions fo the protein. Anal. Biochem. 121:395-408.

40. Bradford, M. 1976. A rapid and sensitive method for the quantitation of microgram quantities of protein using the principle of protein-dye binding. Anal. Biochem. 72:248-254.

41. Williams, S. E., J. D. Ashcom, W. S. Argrawes, and D. K. Strickland. 1992. A novel mechanism for controlling the activity of $\alpha_{2}$-macroglobulin receptor/low density lipoprotein receptor-related protein. Multiple regulatory sites for $39-\mathrm{kDa}$ receptor associated protein. J. Biol. Chem. 267:9035-9040.

42. Orlando, R. A., and M. G. Farquhar. 1993. Identification of a cell line that expresses a cell surface and a soluble form of the gp330/receptor-associated protein (RAP) Heymann Nephritis antigenic complex. Proc. Natl. Acad. Sci. USA. 90:4082-4086.

43. Moestrup, S. K., E. I. Christensen, S. Nielsen, K. E. Jørgensen, S. E Bjørn, H. Røigaard, and J. Gliemann. 1994. Binding and endocytosis of proteins mediated by epithelial gp330. Ann. NY Acad. Sci. 737:124-138.

44. Christensen, E. I., F. A. Carone, and H. G. Reenke. 1981. Effect of molecular charge on endocytic uptake of ferritin in renal proximal tubule cells Lab. Invest. 44:351-358.

45. Christensen, E. I., H. G. Rennke, and F. A. Carone. 1983. Renal tubular uptake of protein: Effect of molecular charge. Am. J. Physiol. F436-F441.

46. Maunsbach, A. B., and E. I. Christensen. 1992. Functional ultrastructure of the proximal tubule. In Handbook of Physiology. Renal Physiology. Section 8. E. E. Windhager, editor Oxford University Press, New York. 41-107.

47. Satrasinh, M., T. C. Knauss, J. M. Weinberg, and H. D. Humes. 1982. Identification of the aminoglycoside binding site in rat renal brush border membrane. J. Pharmacol. Exp. Ther. 222:350-358. 
48. Humes, H. D., M. Satrasinh, and J. M. Weinberg. 1984. Calcium is a competitive inhibitor of gentamicin renal binding interactions and dietary calcium supplementation protects against gentamicin nephrotoxicity. J. Clin. Invest. 73:134-147.

49. Nykjær, A., G. Bengtsson-Olivecrona, A. Lookene, S. K. Moestrup, C. M. Petersen, W. Weber, U. Beisiegel, and J. Gliemann. 1993. The $\alpha_{2}$-macroglobulin receptor/low density lipoprotein receptor-related protein binds lipoprotein lipase and $\beta$-migrating low density lipoprotein associated with lipase. J. Biol. Chem. 268:15048-15055.

50. Chapell, D. A., G. L. Fry, M. A. Waknitz, L. E. Muhonen, M. W. Pladet, P.-H. Iverius, and D. K. Strickland. 1993. Lipoprotein lipase induces catabolism of normal triglyceride-rich lipoproteins via the low density lipoprotein receptorrelated protein/in vitro. A process fascilitated by cell surface proteoglycans. $J$. Biol. Chem. 268:14168-14175.

51. Christensen, E. I., S. Nielsen, S. K. Moestrup, C. Borre, A. B. Maunsbach, E. De Heer, T. G. Hammond, and P. Verroust. 1995. Segmental distribution of the endocytosis receptor gp330 in renal proximal tubules. Eur. J. Cell Biol. 66:349-364.

52. Aubert-Tulkens, G., F. Van Hoof, and P. Tulkens. 1979. Gentamicininduced lysosomal phopholipodosis in cultured rat fibroblasts: a quantitative ultrastructural and biochemical study. Lab. Invest. 40:481-493.
53. D' Amico, D. J., J. Libert, K. R. Kenyon, L. A. Hannien, and L. CaspersVehi. 1985. Retinal toxicity of intraretinal gentamicin. An electron microscopic study IOVS. (Invest. Ophthalmol. \& Visual Sci.) 25:564-572.

54. Hayashida, T., Y. Nomura, M. Iwamori, Y. Nagai, and T. Kurata. 1985 Distribution of gentamicin by immunofluorescence in the guinea pig inner ear. Arch. Otorhinolaryngol. 242:257-264.

55. Van Leuven, F., J.-J. Cassiman, and H. Van den Berghe. 1979. Demonstration of an $\alpha_{2}$-macroglobulin receptor in human fibroblasts. Abscent in tumorderived cell lines. J. Biol. Chem. 254:5155-5160.

56. Warshawsky, I., G. J. Broze, and A. L. Schwartz. 1994. The low density lipoprotein receptor-related protein mediates the cellular degradation of tissue factor pathway inhibitor. Proc. Natl. Acad. Sci. USA. 91:6664-6668.

57. Bysani, G. K., D. C. Stokes, M. Fishman, J. L. Shenep, W. K. Hildner, K. Rufus, N. Bradham, and M. E. Costlow. 1990. Binding of polymyxin B to rat alveolar macrophages. J. Infect. Dis. 162:939-942.

58. Liao, W., and C.-H. Floren. 1993. Polymyxin B complexes with and cationizes low density lipoproteins. Biochem. Pharmacol. 45:1835-1843.

59. Liao, W. and C.-H. Floren. 1992. Polymyxin B enhances low density lipoprotein catabolism in hepatic and extrahepatic cells. Arterioscler. and Thromb. 12:503-511. 